Abstracta Iranica Iranica

Revue bibliographique pour le domaine irano-aryen

Volume 32-33 | 2013

Comptes rendus des publications de 2009-2010

\title{
Homa Katouzian. The Poetry of the Constitutional Revolution
}

Laetitia Nanquette (Bif)

\section{(2) OpenEdition}

1 Journals

Édition électronique

URL : http://journals.openedition.org/abstractairanica/40985

DOI : 10.4000/abstractairanica.40985

ISSN : 1961-960X

\section{Éditeur :}

CNRS (UMR 7528 Mondes iraniens et indiens), Éditions de l'IFRI

\section{Édition imprimée}

Date de publication : 1 décembre 2013

ISSN : 0240-8910

\section{Référence électronique}

Laetitia Nanquette (Bif), « Homa Katouzian. The Poetry of the Constitutional Revolution », Abstracta Iranica [En ligne], Volume 32-33 | 2013, document 436, mis en ligne le 01 juillet 2016, consulté le 30 septembre 2020. URL : http://journals.openedition.org/abstractairanica/40985 ; DOI : https://doi.org/ 10.4000/abstractairanica.40985

Ce document a été généré automatiquement le 30 septembre 2020.

Tous droits réservés 


\title{
Homa Katouzian. The Poetry of the Constitutional Revolution
}

\author{
Laetitia Nanquette (Bif)
}

\section{RÉFÉRENCE}

Homa Katouzian. « The Poetry of the Constitutional Revolution », in : H. E. Chehabi and Vanessa Martin, eds., Iran's Constitutional Revolution. Popular Politics, Cultural

Transformations and Transnational Connections. London, I.B. Tauris, 2010, p. 1-12.

1 Ce chapitre constitue le prologue d'un ouvrage consacré aux aspects socio-culturels de la révolution constitutionnelle. L'A. affirme que la période a vu naître un style poétique original, traitant de sujets politiques dans des formes modernes, et que la révolution constitutionnelle a conduit à une révolution poétique, subvertissant les genres traditionnels et introduisant des thèmes et expressions populaires. L'A. s'intéresse notamment aux poèmes qui critiquent Moḥammad 'Alī Šāh, commentent le renvoi de Morgan Shuster en 1911 ou font directement campagne pour la révolution constitutionnelle, rappelant que ces poèmes ont également contribué au développement du mouvement nationaliste pan-Aryen. Le chapitre donne de nombreux exemples et de longues citations en persan. L'A. analyse certaines images récurrentes dans ces poèmes (le couple mère-nation/enfant-peuple) et certaines formes poétiques (le matnavī est toujours utilisé, mais dans une forme populaire et non plus classique; le poème s'accompagne d'un refrain chanté voire se transforme en berceuse). 


\section{AUTEURS}

LAETITIA NANQUETTE (BIF)

Paris 